\title{
Simultaneous Separation of Ciprofloxacin, Norfloxacin and Ofloxacin by Micellar Electrokinetic Chromatography
}

\author{
Gabriel Hancu,* Aura Rusu, Brigitta Simon, Georgiana Boia and Árpád Gyéresi \\ University of Medicine and Pharmacy, Faculty of Pharmacy, Department of Pharmaceutical \\ Chemistry, GhMarinescu 38, 540139 Târgu Mureş, Romania
}

\begin{abstract}
Este trabalho descreve o desenvolvimento de um método simples de eletroforese capilar (EC) para determinação simultânea dos três derivados mais frequentemente usados da fluoroquinolona: ciprofloxacina, norfloxacina e ofloxacina. Devido às características estruturais e físico-químicas muito semelhantes, ciprofloxacina e norfloxacina não podem ser separadas pelo método clássico de eletroforese capilar de zona (CZE). Suas separações podem ser resolvidas usando cromatografia eletrocinética micelar (MEKC), adicionando um surfactante aniônico à solução-tampão. A eficiência da separação pode ser intensificada através da otimização de parâmetros analíticos. Um método rápido e confiável foi desenvolvido, e os melhores resultados foram obtidos usando uma soluçãotampão contendo tetraborato de sódio $25 \mathrm{mmol} \mathrm{L}^{-1}$, dodecilsulfato de sódio $100 \mathrm{mmol} \mathrm{L}^{-1}$ e metanol $5 \%$ como modificador orgânico.
\end{abstract}

This work describes the development of a simple capillary electrophoresis (CE) method for simultaneous determination of the three most frequently used fluoroquinolone derivatives: ciprofloxacin, norfloxacin and ofloxacin. Due to very similar structural and physicochemical characteristics, ciprofloxacin and norfloxacin cannot be separated by the classic method of capillary zone electrophoresis (CZE). Their separations can be solved using micellar electrokinetic chromatography (MEKC), by adding an anionic surfactant to the buffer solution. The efficiency of the separation can be enhanced through the optimization of analytical parameters. A fast reliable method was developed, and the best results were obtained using a buffer solution containing $25 \mathrm{mmol} \mathrm{L}^{-1}$ sodium tetraborate, $100 \mathrm{mmol} \mathrm{L}^{-1}$ sodium dodecyl sulphate and $5 \%$ methanol as organic modifier.

Keywords: fluoroquinolones, micellar electrokinetic chromatography, ciprofloxacin, norfloxacin, ofloxacin

\section{Introduction}

Fluoroquinolones (FQs) are synthetic broad-spectrum chemotherapeutic antibacterial substances, widely used do to their enhanced pharmacokinetic properties, particular mechanism of action and extensive and potent activity. FQ is one of the fastest growing antibacterial class in terms of therapeutic use and global revenue, being increasingly used in both hospital and community sectors to treat a wide range of infections, challenging the predominance of wellestablished $\beta$-lactam antibiotics which are becoming more prone to the resistant pathogenic bacteria. ${ }^{1}$

Since the discovery of nalidixic acid in 1962, the development of FQs has experienced an exponential

*e-mail: g_hancu@yahoo.com growth, which continues today in order to obtain better drugs having multifunctional action.

Their great therapeutic importance is closely linked with the analytical problems; consequently the elaboration of new methods for their analysis is a permanent necessity and also a challenge. The most frequently applied methods for the analysis of FQ are the chromatographic ones, especially high performance liquid chromatography (HPLC), which is also recommended in the European Pharmacopoeia (Ph.Eur.7). ${ }^{2}$ Capillary electrophoresis (CE) is an officinal method of analysis of drugs in the Ph.Eur.7 based on migration of charged particles dissolved or spread in an electrolyte solution, in which the separation occurs in fused-silica capillaries and involves application of high voltages across the buffer filled capillary. ${ }^{2}$ Due to its speed of analysis, high separation efficiency, low reagent and 
sample consumption and rapid method development, CE has gained momentum in pharmaceutical analysis, being regarded today as an alternative and also a complementary technique to the more frequently used HPLC. ${ }^{3}$

CE proved to be an important tool in the analysis of FQ derivatives but the large majority of the developed methods describe separation of FQs from different generations having different physicochemical characteristics. ${ }^{4-8}$

Ciprofloxacin (CIP), norfloxacin (NOR) and ofloxacin $(\mathrm{OFL})$ (three $2^{\text {nd }}$ generation $\mathrm{FQs}$ ) are by far the important and widely used FQs. CIP and NOR have almost similar structural characteristics, the substituent at the nitrogen atom from the pyridin-carboxilic ring (cyclopropyl and ethyl side chain, respectively) being the only difference between the two, while OFL is a tricyclic derivative and has a methyl substituent on the piperazine ring (Figure 1). ${ }^{9}$<smiles>Cn1cc(C(=O)O)c(=O)c2cc(F)c(N3CCNCC3)cc21</smiles><smiles>CC1COc2c(N3CCN(C)CC3)c(F)cc3c(=O)c(C(=O)O)cn1c23</smiles>

Figure 1. The chemical structures of the studied fluoroquinolones (FQs).

Some CE methods have been developed for the determination of CIP, NOR and OFL, but their simultaneous determination is challenging because of their similar electrophoretic mobilities. ${ }^{6,7}$

The aim of our study was to prove the applicability of the CE method for the simultaneous separation of the studied FQs by developing a rapid, simple and sensitive procedure for their simultaneous determination and also to conduct a systematic study of the analytical conditions (i.e., the effects of buffer concentration, modifier concentration and buffer $\mathrm{pH})$ in order to improve the separation.

\section{Experimental}

Instrumentation

All experiments were performed using an Agilent 6100 CE system (Agilent Technologies, Germany) equipped with diode-array detector. The results were recorded and processed using Chemstation 7.01 software (Agilent Technologies, Germany). In all measurements, hydrodynamic sample injection was used, by applying a pressure of 50 mbar for $5 \mathrm{~s}$. The running voltage was $+20 \mathrm{kV}$. The generated current was kept below $200 \mu \mathrm{A}$. The capillary temperature was set at $20^{\circ} \mathrm{C}$. The sample solutions were injected at the anodic end of the capillary, with the detector at the cathodic end. Separations were performed using an uncoated fused-silica capillary of $48.5 \mathrm{~cm} \times 50 \mu \mathrm{m}$ i.d. (effective length $40 \mathrm{~cm}$ ) (Agilent Technologies, Germany). The detection was carried out in $\mathrm{UV}$ at $280 \mathrm{~nm}$. The individual compounds were identified in the mixture by their UV spectra and migration time.

\section{Chemicals and samples}

All studied FQs were of pharmaceutical quality: ciprofloxacin, norfloxacin (Sandoz, Romania) and ofloxacin (Ranbaxy, Romania).

Reagents that were used: sodium tetraborate, sodium dodecyl sulphate (SDS), sodium hydroxide, phosphoric acid (Merck, Germany). Solvents that were used: methanol $(\mathrm{MeOH})$, acetonitrile (ACN) (Merck, Germany). All reagents were of analytical grade and solvents were of chromatographic purity. Deionized water (Milli-Q Water System) was used for preparing solutions throughout the experiments.

Stock solutions $\left(100 \mathrm{mg} \mathrm{L}^{-1}\right)$ of each FQs were prepared by dissolving separately the studied FQs in $\mathrm{MeOH}$ and then diluting the solution with water (1:1). Prior to measurements, all samples and buffers were filtered through a $0.45 \mu \mathrm{m}$ syringe filter, and the samples were stored in the refrigerator at $4{ }^{\circ} \mathrm{C}$. At the beginning of each day, the capillary was conditioned with $0.1 \mathrm{~mol} \mathrm{~L}^{-1}$ sodium hydroxide $(5 \mathrm{~min})$, deionized water ( $5 \mathrm{~min}$ ) and electrolyte solution ( $5 \mathrm{~min}$ ). The capillary was preconditioned before every run with deionized water (2 $\mathrm{min}$ ) and electrolyte solution (3 $\mathrm{min})$.

\section{Results}

\section{Preliminary study}

In order to choose the most efficient buffer solution, an important parameter to be considered is the acid-base properties of the analytes, expressed by the $\mathrm{pKa}$ values.

FQs are amphoteric substances and will be negatively or positively charged depending on the $\mathrm{pH}$ of the environment, offering the possibility of using either an acidic or an alkaline running buffer for their separation. ${ }^{6,8}$

The two pKa values correspond to the acid carboxyl group from the piperidine ring respectively to the free 
nitrogen from the piperazine ring. CIP and NOR exhibit very close values for both $\mathrm{pKa} 1$ and $\mathrm{pKa} 2$ due to structural similiarities, while the pKa values for OFL are smaller due to its tricyclic structure and substitution on the piperazine ring. ${ }^{10}$ The pKa values of the three compounds are presented in Table $1 ., 5,8$

Table 1. The pKa values of ciprofloxacin (CIP), norfloxacin (NOR) and ofloxacin (OFL)

\begin{tabular}{lcc}
\hline Analyte & pKa1 $(-\mathrm{COOH})$ & $\mathrm{pKa} 2(-\mathrm{NH})$ \\
\hline CIP & 6.27 & 8.87 \\
NOR & 6.34 & 8.75 \\
OFL & 5.97 & 7.65 \\
\hline
\end{tabular}

Initial runs were carried out to assess the feasibility of borate and phosphate buffers as background electrolytes. These preliminary experiments showed better results when using a buffer containing sodium tetraborate ( $\mathrm{pH}$ 9.3) in order to obtain high resolution within shortest analysis time. It was assumed that the best separation based on these parameters is expected at a $\mathrm{pH}$ value above 8.87 , in which all the compounds would be analyzed as anions.

\section{Optimization of the separation method}

Our aim was not only the elaboration of a CE method for simultaneous screening of the studied FQs, but also the optimization of the separation conditions in order to understand and improve the separation process.

Separation using capillary zone electrophoresis (CZE) (the simplest electrophoretic procedure) is based on the differences between the electrophoretic mobilities of the analytes, therefore, it is hard to achieve an efficient separation between CIP and NOR.
An increase in the electrolyte concentration increased the migration time of the analytes due to the decrease of the electrosmotic flow (EOF), without improving the resolution of the separation.

The studied FQs exist as zwitterions due to the presence of both nitrogen atom (proton acceptor) and a carboxylic group (proton donor), so variations in buffer $\mathrm{pH}$ would change their surface charge densities and mobilities, influencing separation efficiency. ${ }^{11}$

To determine the optimum $\mathrm{pH}$, the $\mathrm{pH}$ values between 8 and 11 were examined and, the migration times and also the resolution increased at higher $\mathrm{pH}$ values. At $\mathrm{pH}$ values lower than 8.87 , the peaks became wide and then completely distorted probably because of the total ionization of the analytes. The buffer $\mathrm{pH}$ was adjusted by adding $0.1 \mathrm{~mol} \mathrm{~L}^{-1}$ $\mathrm{NaOH}$, respectively, $0.1 \mathrm{~mol} \mathrm{~L}^{-1} \mathrm{HCl}$ solutions to the buffer.

Various buffer additives such as SDS or organic solvents can be employed to improve the selectivity of the separation. ${ }^{10,12}$

Addition of $\mathrm{MeOH}$ changes the polarity and increases the viscosity of the buffer, thus modifying the electrophoretic mobility of the analytes. An increase in the $\mathrm{MeOH}$ concentration led to an increase in the migration times of the analytes because of the decrease of EOF, but also to an improvement of the separation efficiency. The use of ACN as organic additive proved to be less effective in improving separation.

Using a buffer containing $25 \mathrm{mmol} \mathrm{L} \mathrm{L}^{-1}$ sodium tetraborate and $15 \% \mathrm{MeOH}(\mathrm{pH} 10.5)$, it was possible to separate OFL from the pair CIP-NOR (Figure 2).

CZE can be successfully used for the separation of OFL from the other two FQs, but CIP and NOR could not be separated by this method.

The separation between CIP and NOR can be solved by micellar electrokinetic chromatography (MEKC).

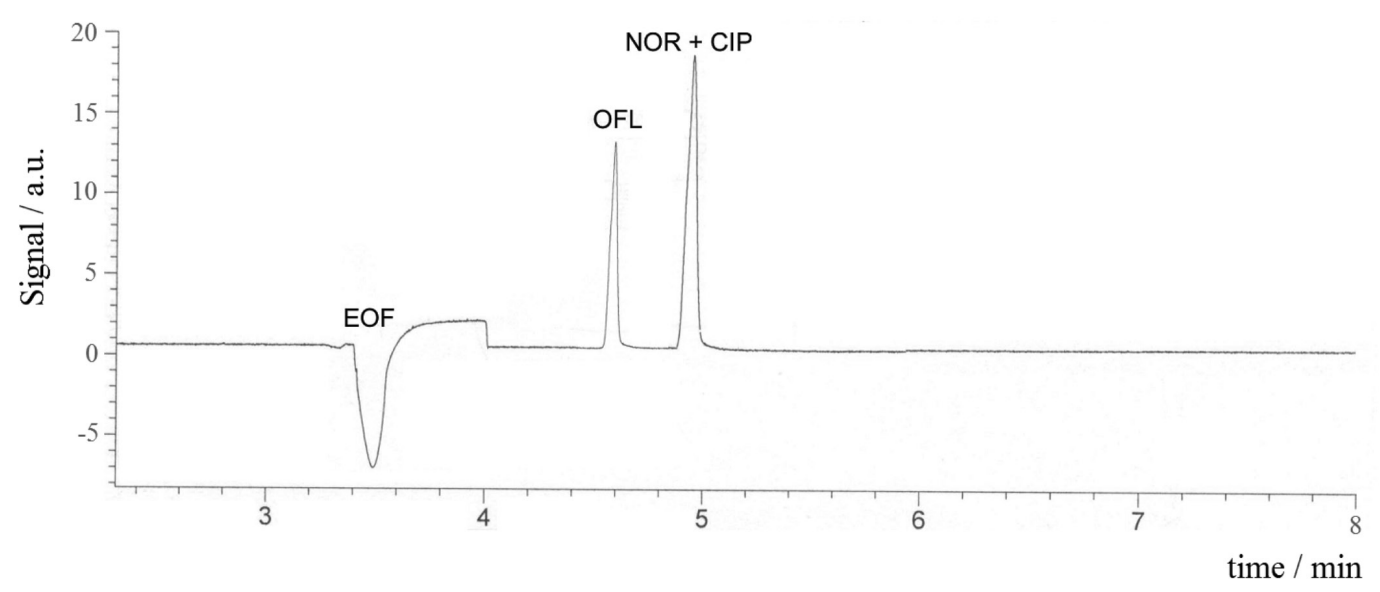

Figure 2. Separation of the three studied fluoroquinolones (FQs) by capillary zone electrophoresis (CZE). Buffer: $25 \mathrm{mmol} \mathrm{L}^{-1}$ sodium tetraborate $+15 \%$ $\mathrm{MeOH}, \mathrm{pH} 10.5$, voltage: $+20 \mathrm{kV}$, temperature $20^{\circ} \mathrm{C}$, detection: $\mathrm{UV}$ absorption at $280 \mathrm{~nm}$, injection pressure: 50 mbar for $5 \mathrm{~s}$, capillary: $48.5 \mathrm{~cm}$ (effective length $40 \mathrm{~cm}) \times 50 \mu \mathrm{m}$ i.d., concentration of each analyte: $25 \mathrm{mg} \mathrm{L}^{-1}$. 
MEKC is a hybrid method, combining electrophoretic and chromatographic separation procedures, which can be applied for the separation of both neutral and charged analytes. $^{12}$

The addition of a surfactant (SDS) in the running buffer over its critical micellar concentration (CMC) generates aggregation of the surfactant molecules and formation of micelles in the running buffer, causing changes of the apparent mobility of the analytes due to hydrophobic interactions.

With the increase of the SDS concentration, the migration time of analytes increased due to solubilization in the micellar phase. An increase in SDS concentration led to an improved separation resolution (Figure 3).

It is interesting that in MEKC, an increase of the buffer $\mathrm{pH}$ did not influence positively the separation like in CZE. The addition of an organic solvent $(\mathrm{MeOH}, \mathrm{ACN})$ to the

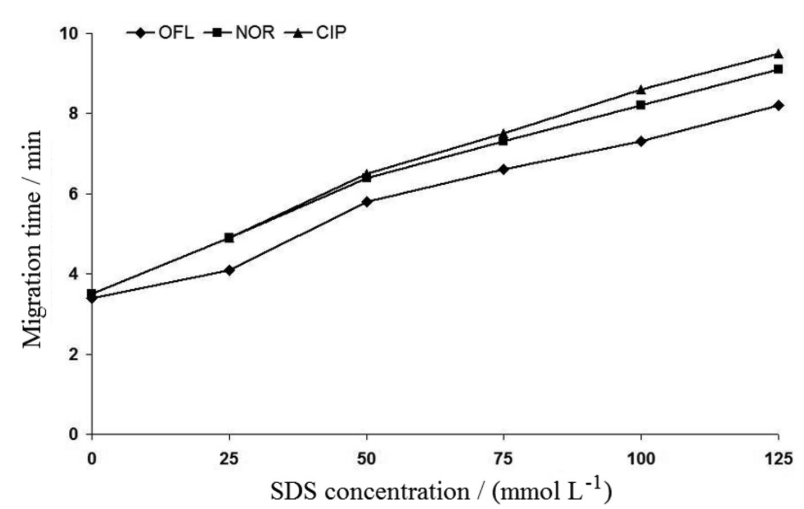

Figure 3. Variation of migration time of the fluoroquinolones (FQs) depending on the anionic surfactant (SDS) concentration. Buffer: $25 \mathrm{mmol} \mathrm{L}^{-1}$ sodium tetraborate + 0-100 $\mathrm{mmol} \mathrm{L}^{-1} \mathrm{SDS}, \mathrm{pH} 9.3$, voltage: $+20 \mathrm{kV}$, temperature $20^{\circ} \mathrm{C}$, detection: $\mathrm{UV}$ absorption at $280 \mathrm{~nm}$, injection pressure: $50 \mathrm{mbar}$ for $5 \mathrm{~s}$, capillary: $48.5 \mathrm{~cm}$ (effective length $40 \mathrm{~cm}) \times 50 \mu \mathrm{m}$ i.d., concentration of each analyte: $25 \mathrm{mg} \mathrm{L}^{-1}$. micellar solution brought a slight improvement of the separation. However, high concentration of $\mathrm{MeOH}$ (above $15 \%$ ) decreased dramatically the separation efficiency probably because of the deterioration of the micellar structure.

The increase in applied voltage increased the electrophoresis current, decreased migration time of the analytes, but also increased Joule heating, which decreases the separation efficiency.

Migration time and separation resolution increased with the decrease of capillary temperature. In MEKC, the distribution coefficients are highly dependent on temperature; an increase in temperature will cause a decrease in the distribution coefficient of the analytes between the two phases.

The best separation occurred using a buffer solution containing $25 \mathrm{mmol} \mathrm{L}^{-1}$ sodium tetraborate, $100 \mathrm{mmol} \mathrm{L}^{-1}$ SDS and $5 \% \mathrm{MeOH}$, when it was achieved a baseline separation of the analytes in less then $10 \mathrm{~min}$. The separation occurred in the following order: OFL, NOR and CIP (Figure 4).

\section{Discussion}

MEKC is based on the addition of a micellar "pseudostationary" phase to the buffer solution, which interacts with the analytes according to partitioning mechanisms, in a chromatography-like mode; EOF acting as the chromatographic "mobile phase". In this case, the "pseudostationary" phase is composed of an anionic surfactant, SDS. The anionic SDS micelles are electrostatically attracted towards the anode, but, because of the prevalent velocity of EOF, they slowly migrate towards the cathode. Separation will depend on the individual

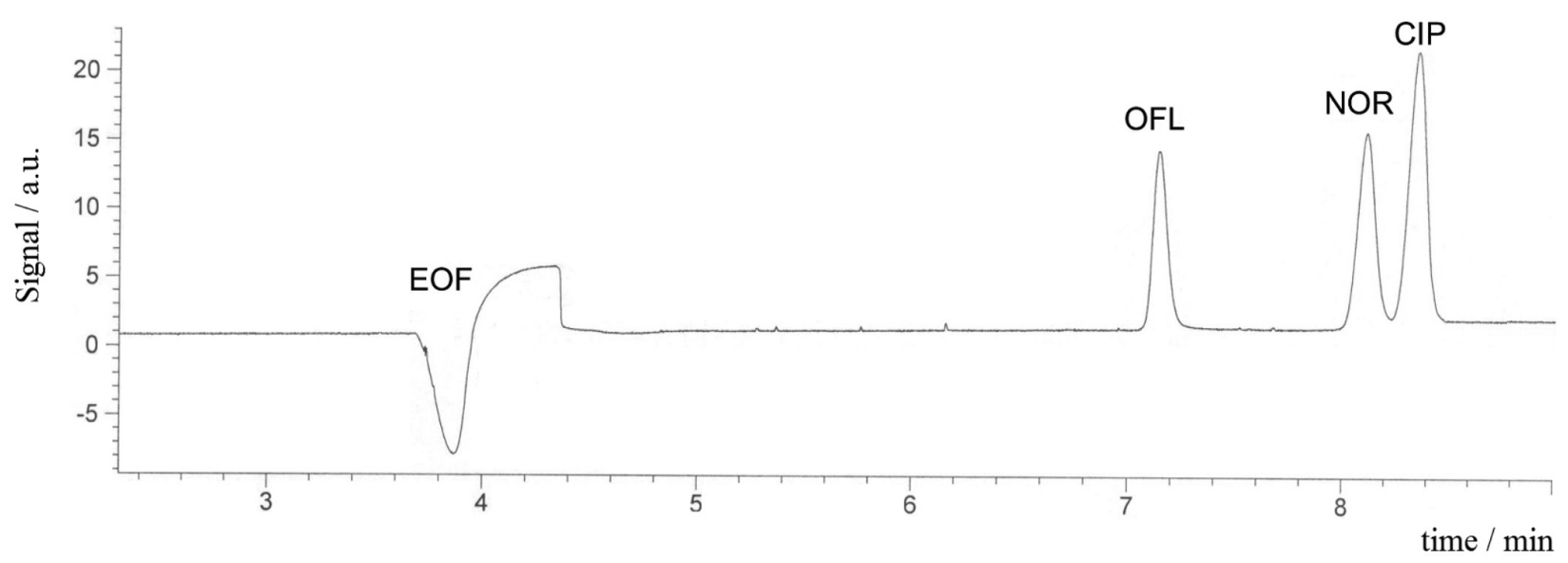

Figure 4. Separation of the three studied fluoroquinolones (FQs) by micellar electrokinetic chromatography (MEKC). Buffer: 25 mmol L-1 sodium tetraborate $+100 \mathrm{mmol} \mathrm{L}^{-1} \mathrm{SDS}+5 \% \mathrm{MeOH}, \mathrm{pH} 9.3$, voltage: $+20 \mathrm{kV}$, temperature $20^{\circ} \mathrm{C}$, detection: UV absorption at $280 \mathrm{~nm}$, injection pressure: $50 \mathrm{mbar}$ for $5 \mathrm{~s}$, capillary: $48.5 \mathrm{~cm}$ (effective length $40 \mathrm{~cm}$ ) $\times 50 \mu \mathrm{m}$ i.d., concentration of each analyte: $25 \mathrm{mg} \mathrm{L}^{-1}$. 


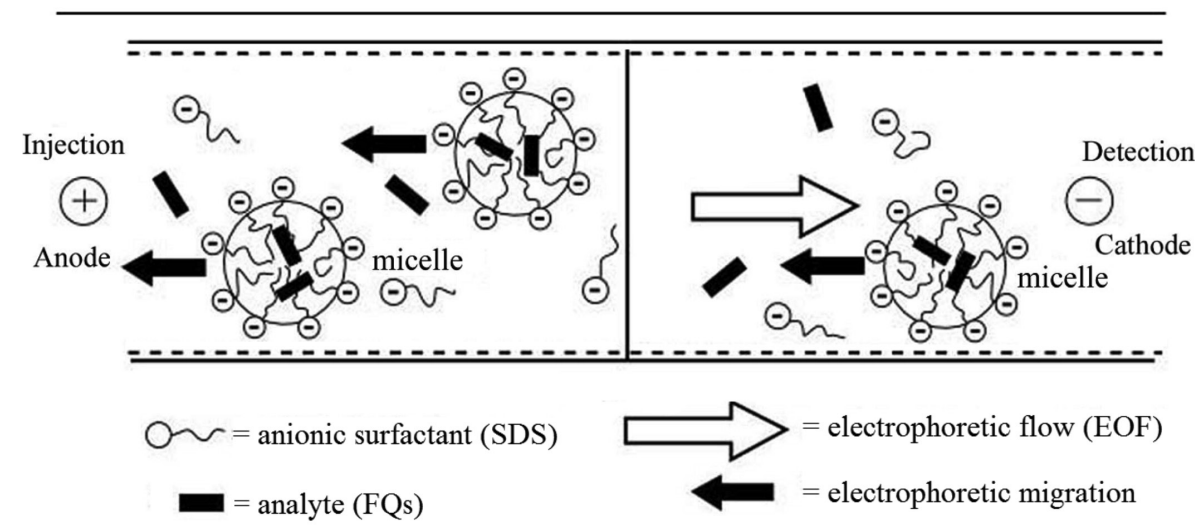

Figure 5. Schematic of the separation principle in micellar electrokinetic chromatography (MEKC).

partitioning equilibrium of the studied analytes between the hydrophobic core of the micelles and the aqueous buffer (Figure 5).,12

The migration order of these compounds is governed by a combined effect of their hydrophobicities (incorporation into the hydrophobic sites of the micelles) and their positive charge (ionic interactions between the negatively charged micelle surface and the cationic part of the analytes). The migration is under counter-electroosmotic flow rate

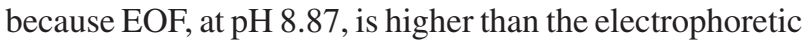
mobility of the studied FQs, carrying them towards the detector.

Analytes that have greater affinity for the micelle have slower migration velocities compared to analytes that spend most of their time in the bulk phase. Because of its tricyclic structure, OFL is less incorporated into the micelles in comparison with the other two bicyclic derivatives, therefore will migrate faster.

Generally high surfactant concentrations increase buffer viscosity and current intensity, and should be avoided; but in this case, in order to achieve separation, it was necessary to use a relatively high concentration $\left(100 \mathrm{mmol} \mathrm{L}^{-1} \mathrm{SDS}\right)$ and to compensate the generation of high currents by decreasing the applied voltage and capillary temperature.

$\mathrm{MeOH}$ was used to reduce the hydrophobic interactions between analyses and micelles and, consequently, to increase their migration velocity.

\section{Analytical performance}

The separation method was evaluated by calculation of relative standard deviation (RSD) for migration time and peak area, limits of detection (LOD) and quantification (LOQ) and also by checking up the linearity of the determination.

Very similar migration times and peak areas were obtained for six repeated measurements, RSDs were smaller than $1 \%$ indicating a good precision of the method. As it is usual, the precision for migration times was better than for peak areas (Table 2).

LOD was determined as the sample concentration that produces a peak with a height three times the level of the baseline noise, and LOQ was defined as a peak with 10 times the signal-to-noise ratio (Table 2).

Plotting the calibration graphs, it was calculated the individual linear regression equation and the correlation coefficient for each FQ injecting six solutions with different concentrations in a specific range and three replicates per concentration (Table 3). All correlation coefficients were over 0.99 , which demonstrates a very good linearity of the method.

Another method to verify linearity was to apply a lack of fit ANOVA (analysis of variance) test, a statistical test that has an $F$-distribution under the null hypothesis. The calculated $F$-value was below the $F$-critical value (3.68),

Table 2. Analytical parameters of the fluoroquinolone (FQ) separation

\begin{tabular}{lcccccc}
\hline Analyte & $\begin{array}{c}\text { Average migration } \\
\text { time / min }\end{array}$ & $\begin{array}{c}\text { Electrophoretic } \\
\text { mobility / } \\
\left(\mathrm{cm}^{2} \mathrm{kV}^{-1} \mathrm{~min}^{-1}\right)\end{array}$ & $\begin{array}{c}\text { RSD / \%, } \\
\text { migration time }\end{array}$ & $\begin{array}{c}\text { RSD / \%, } \\
\text { peak area }\end{array}$ & $\begin{array}{c}\text { LOD / } \\
\left(\mathrm{mg} \mathrm{L}^{-1}\right)\end{array}$ & $\begin{array}{c}\text { LOQ / } \\
\left(\mathrm{mg} \mathrm{L}^{-1}\right)\end{array}$ \\
\hline OFL & 7.32 & -8.85 & 0.087 & 0.507 & 2.49 & 8.30 \\
NOR & 8.19 & -10.25 & 0.087 & 0.766 & 2.28 & 7.89 \\
CIP & 8.54 & -10.66 & 0.094 & 0.952 & 2.07 & 7.53 \\
\hline
\end{tabular}

RSD: relative standard deviation; LOD: limit of detection; LOQ: limit of quanfication. 
Table 3. Linearity regression data of the fluoroquinolone (FQ) separation (concentration range 5-100 $\mathrm{mg} \mathrm{L}^{-1}$ )

\begin{tabular}{lcccc}
\hline Analyte & Slope & Intercept & $\begin{array}{c}\text { Correlation } \\
\text { coefficient }\end{array}$ & $F_{\text {calculated }}$ \\
\hline OFL & 0.3862 & 15.195 & 0.996 & 3.03 \\
NOR & 0.5416 & 20.173 & 0.995 & 3.16 \\
CIP & 0.7734 & 28,340 & 0.993 & 3.35 \\
\hline
\end{tabular}

consequently linearity can be considered suitable in the studied concentration range. ${ }^{5}$

\section{Conclusions}

CE proved to be a significant and versatile technique for the simultaneous separation of structure-related FQ derivatives. With the classic CZE, only OFL was separated from CIP and NOR. The simultaneous baseline separation of the three studied FQs was solved by using MEKC. Separation of several QNs from a complex mixture is probably beyond the capacity of MEKC. However this method can be useful as an auxiliary technique to separate those QNs that cannot be separated by CZE (for example CIP and NOR), from a mixture of a few components.

A mixture of FQs is generally not used in medicine, so their simultaneous determination from biological fluids is rarely necessary; but complex mixtures are often found in environmental samples (water, soil). The reason to study the three most frequently used FQs was to prove the applicability of MEKC for the analysis of FQs in general, and for the separation of structure-related derivatives in particular.

Using the described optimized conditions, the technique can be used successfully for the analysis and identity confirmation of drugs in formulated products and also for the investigation of complex mixtures of drugs; other FQs can probably be likewise analyzed.

\section{References}

1. Sweetman, S. C.; Martindale: The Complete Drug Reference, $36^{\text {th }}$ ed.; Pharmaceutical Press: London, UK, 2009.

2. European Pharmacopoeia, $7^{\text {th }}$ ed.; Council of Europe: Strasbourg, France, 2010.

3. Schmitt-Kopplin, P.; Capillary Electrophoresis - Methods and Protocols; Humana Press: Totowa, NJ, USA, 2008.

4. Faria, A. D.; de Souza, M. V. N.; de Almeida, M. V.; de Oliveira, M. A. L.; Anal. Chim. Acta 2006, 579, 185.

5. Faria, A. D.; de Souza, M. V. N.; de Oliveira, M. A. L.; J. Braz. Chem. Soc. 2008, 19, 389.

6. Ferdig, M.; Kaleta, A.; Vo, T. D. T.; Buchberger, B.; J. Chromatogr., A 2004, 1047, 305.

7. Fierens, C.; Hillaert, S.; van den Bossche, W.; J. Pharm. Biomed. Anal. 2000, 22, 763.

8. Sun, H.; He, P.; Lv, Y.; Liang, S.; J. Chromatogr., B: Anal. Technol. Biomed. Life Sci. 2007, 852, 145.

9. Block, J. H.; Beale, J. M.; Wilson\&Gisvold Textbook of Organic Medicinal and Pharmaceutical Chemistry, $11^{\text {th }}$ edition; Lippincott Williams\&Wilkins: Philadelphia, 2004.

10. Mamami, M. C. V.; Amaya-Farfan, J.; Reyes, F. G.; da Silva, J. A. F.; Rath, S.; Talanta 2008, 76, 1006.

11. Yang, Z.; Qin, W.; J. Chromatogr., A 2009, 1216, 5327.

12. Landers, J. P.; Handbook of Capillary and Microchip Electrophoresis and Associated Microtechniques; CRC Press: Boca Raton, FL, USA, 2008.

Submitted: February 17, 2012

Published online: October 19, 2012 